\section{Funnel trap as a method for capture migrating bats in Pape, Latvia}

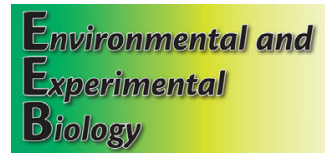

ISSN 2255-9582

\section{Oskars Keišs ${ }^{1 *}$, Donats Spalis', Gunārs Pētersons²}

${ }^{1}$ Laboratory of Ornithology, Institute of Biology, University of Latvia, Jelgavas 1, Rīga LV-1004, Latvia ${ }^{2}$ Faculty of Veterinary Medicine, Latvia University of Life Sciences and Technologies, Kristapa Helmaña 8, Jelgava LV-3004, Latvia

*Corresponding author, E-mail: oskars.keiss@lu.lv

\begin{abstract}
We constructed a large funnel trap on the coast of the Baltic Sea on dunes of Pape village, Latvia. The trap has been used during the peak autumn migration of bats in Latvia in August and September. During the period of $2014-2020$, about 40 thousand bats were captured in the trap, mostly Nathusius' Pipistrelle Pipistrellus nathusii, about 35 thousand individuals. In migration hotspots of bats, this is suggested method of trapping since large number of bats might be trapped without entangling bats in mist-nets.
\end{abstract}

Key words: bat migration, funnel Heligoland trap, Pipistrellus nathusii.

\section{Introduction}

Research on bird and bat migration usually includes also capture of animals. A problem with bird captures with mist nets often arises when there are several hundred birds entangled in one mist-net and the capacity of ringers is limited. Bats during migration are usually scarce and there are too few captured due to lower concentrations of bats and higher migration altitude (mist nets are usually limited to $2 \mathrm{~m}$ above the ground). A funnel trap for bird research was first built on Heligoland Island, Germany in 1920 by Dr. Hugo Weigold (Weigold 1922; Weigold 1924; Weigold 1956; Woodford, Hussel 1961) and therefore later funnel traps for bird trapping have often been referred as "Heligoland traps". However, funnel traps were constructed previously for trapping thrushes (Turdus spp.) for food (Gatke 1895). In 1957 in Rybatschi Ornithological station (former Vogelwarte Rossitten of Germany) on the Curonian Spit, a large Heligoland trap was designed and built by Jānis Jakšis and team of the station (Belopolskii 1961). This large Heligoland trap is also referred to as the "Rybatschi trap" (Payevsky 2000).

Survey of the best place for establishing a bird observatory in Latvia for research of autumn migration of birds was done in autumn of 1958 (Mihelsons et al. 1960). The results of a month of observations between September 15 and October 15 indicated two locations with considerable bird concentrations: Salacgriva and Pape (Fig. 1). The Bird Observatory at the Baltic Sea coast in Pape village was established in 1966 (Blūms et al. 1966; Baumanis 1995) and the first Rybatschi type trap was built in 1968. However, in 1985 it was noticed that also migrating bats could be observed and captured in great numbers in the trap (Celminš et al. 1986). Harp traps for bats (Tuttle 1974; Masing 1989) were built inside the final tunnel of the Rybatschi trap, but they were relatively ineffective in

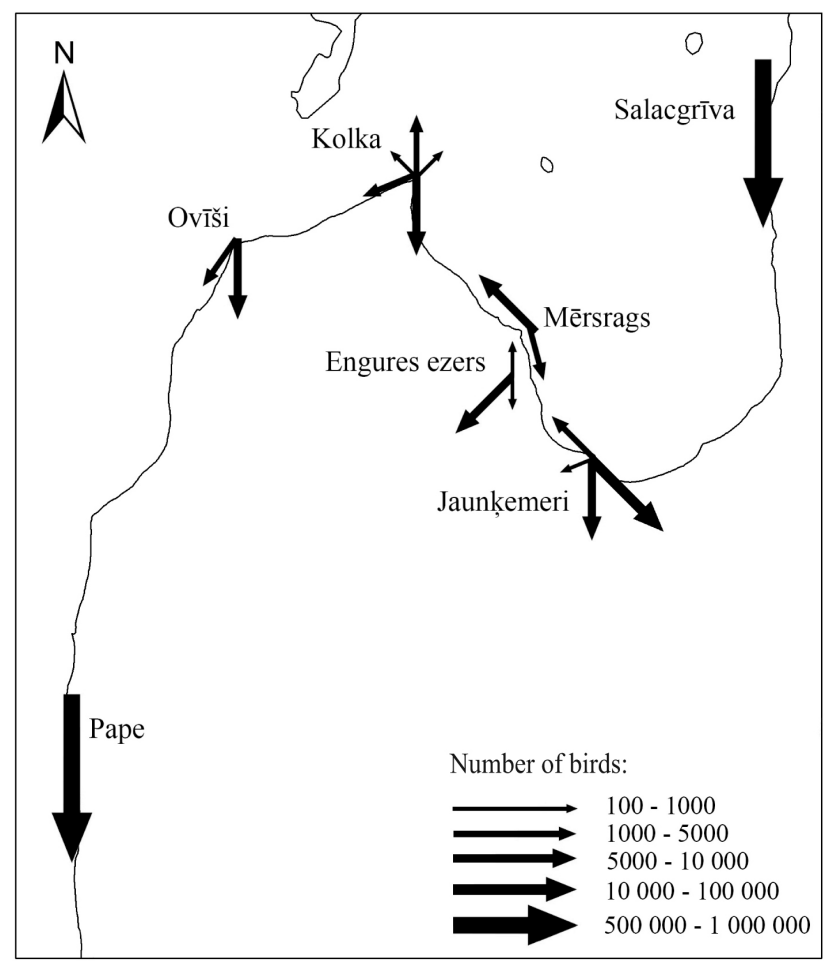

Fig. 1. Estimated numbers of migrating Passerine birds at coastal locations of Latvia, autumn 1958, when the choice to establish Ornithological station in Pape was made (redrawn after Mihelsons et al. 1960). 


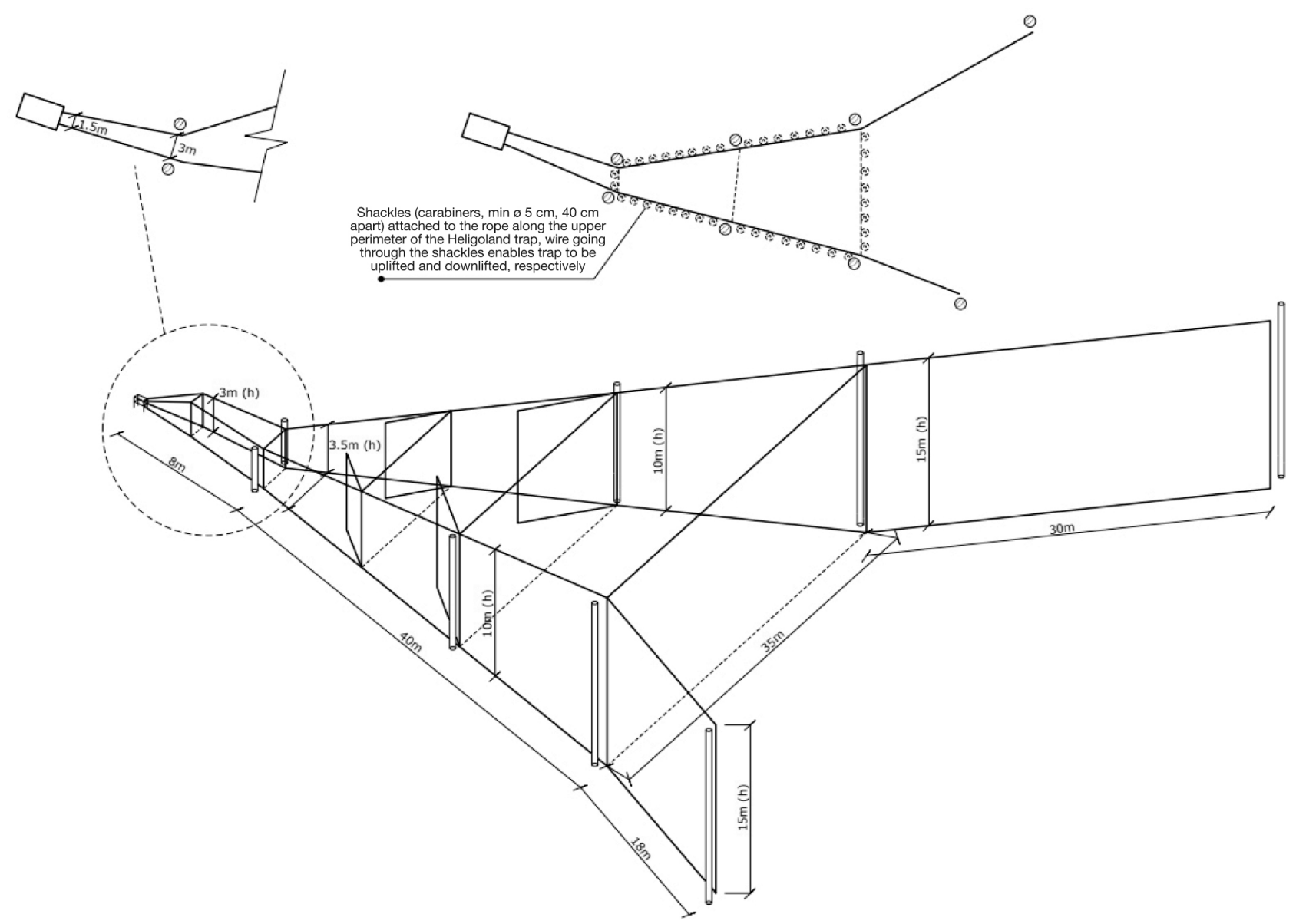

Fig. 2. Scheme of the trap build in Pape in 2014 for bat trapping (drawing by Reinis Priedols).

comparison to active trapping of bats flying in the tunnel by butterfly net (Pētersons 2004).

\section{Construction of the funnel trap}

An overall scheme of a Helgoland trap was published by Woodford and Hussel (1961), but each Helgoland type and Rybatschy type trap varies depending on the local relief and other characteristics of the surroundings and possibilities. The trap we designed and constructed in 2014 in Pape, Latvia was aimed at bat capture during the autumn migration in August - September (before autumn storm season starts at the Baltic Sea). At the entrance it was $15 \mathrm{~m}$ high and the end corridor was $2.0 \mathrm{~m}$ high; the width of the trap at the entrance was $35 \mathrm{~m}$ and $1.5 \mathrm{~m}$ at the end corridor (Fig. 2). The mesh size was $18 \times 18 \mathrm{~mm}$ at the beginning of the trap, $12 \times 12 \mathrm{~mm}$ at the end corridor and $8 \times 8 \mathrm{~mm}$ at the end box in order to prevent birds and bats of smaller species to escape through the mesh at the end of the trap. The trap was attached to six poles $15 \mathrm{~m}$ high and two poles $3 \mathrm{~m}$ high (Fig. 3 and 4), produced in Latvia ("Jauda-Koks", LV-5060 Suntaži) for electrical wires. The poles are stationary in the field all year round, but the trap is installed each year at the beginning of August and removed in the middle of September. The trap can be lifted for catching, and lowered during storms, by six winches. Of the six poles with height $15 \mathrm{~m}$, one broke in the 6th year of usage in 2019 (during a storm on September 10 when the trap was installed and lowered). This pole was replaced in 2020 before the beginning of the season.

\section{Scientific use of the trap}

The trap has been very successful in capture of migrating bats. The total number of captured individuals of 15 bat species during the period 2014 - 2020 was 40896 (Table 1). The only Latvian bat species captured in Pape before this trap was build, in 1988 (Pētersons, Celmiņš 1989), but not during the period of 2014 - 2020, was the greater mouse-eared bat (Myotis myotis). The majority of the captured individuals (35 396) were Nathusius' pipistrelles (Pipistrellus nathusii), with maximum captures being 14 171 in 2018 (Table 1). On average during this period (2014 - 2020) there were more captures per year (5842) than ever previously, up to 3975 in 1990 (Pētersons 2004), on average 2546 per year $(1988$ - 1991). These data are given here only as an example, since explicit analyses of bat migration data are given in specific articles (e.g., Petersons 2004; Lindecke 


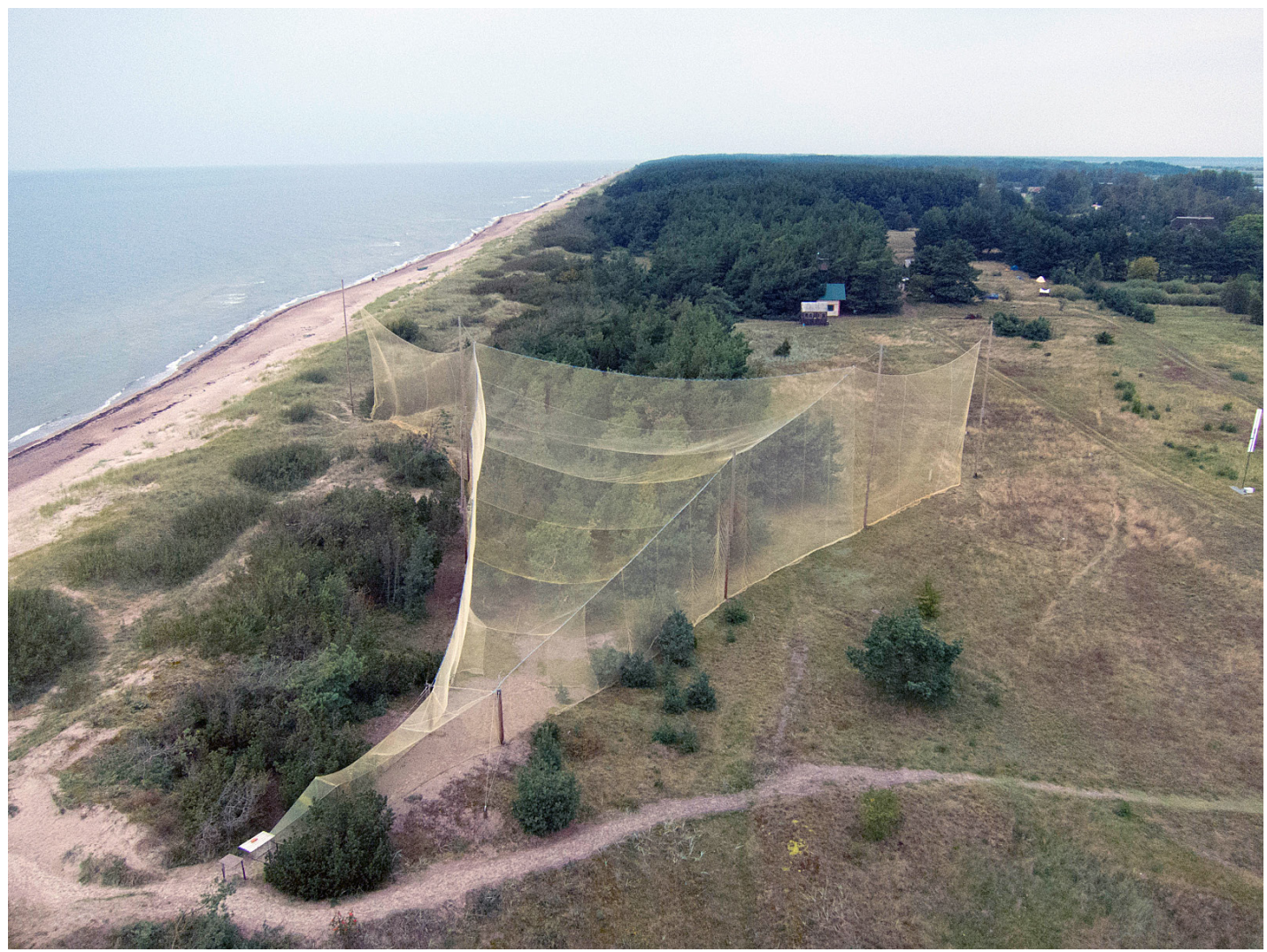

Fig. 3. Pape trap from above (photo by Jasja Dekker).

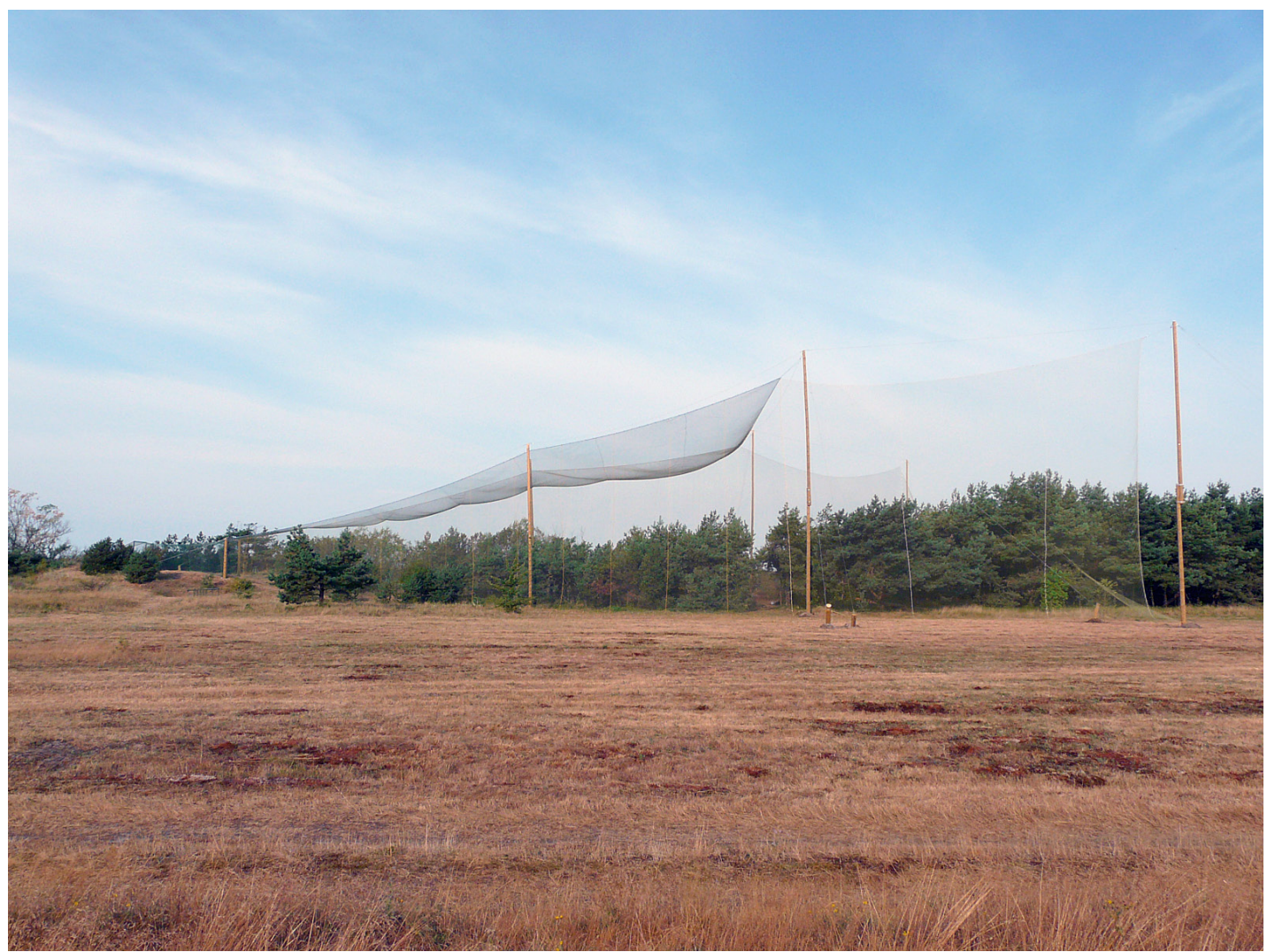

Fig. 4. Pape trap from Eastern (inland) side (photo by Gunārs Pētersons). 
Table 1. Number of bat species and individuals captured in the Pape trap in $2014-2020$

\begin{tabular}{|c|c|c|c|c|c|c|c|c|}
\hline Species / species group & 2014 & 2015 & 2016 & 2017 & 2018 & 2019 & 2020 & $\begin{array}{c}\text { Total } 2014 \\
-2020\end{array}$ \\
\hline Pipistrellus nathusii & 1596 & 2172 & 4864 & 2038 & 14171 & 6583 & 3972 & 35396 \\
\hline Pipistrellus pipistrellus & - & - & - & 5 & 1 & - & - & 6 \\
\hline P. pipistrellus / pygmaeus & - & - & 1 & - & - & - & - & 1 \\
\hline Pipistrellus pygmaeus & 83 & 222 & 741 & 421 & 529 & 1171 & 595 & 3762 \\
\hline Nyctalus noctula & 4 & 7 & 32 & 32 & 75 & 270 & 39 & 459 \\
\hline Nyctalus leisleri & - & 1 & - & - & - & 5 & - & 6 \\
\hline Vespertilio murinus & 14 & 17 & 76 & 110 & 261 & 329 & 53 & 860 \\
\hline Eptesicus nilssonii & 2 & 4 & 22 & 55 & 25 & 46 & 18 & 172 \\
\hline Eptesicus serotinus & 2 & 1 & 1 & 3 & 8 & 7 & 2 & 24 \\
\hline Myotis dasycneme & - & 2 & 1 & - & - & - & - & 3 \\
\hline Myotis daubentonii & 2 & 2 & 7 & 9 & 7 & 10 & 12 & 49 \\
\hline Myotis brandtii & 1 & 3 & 7 & 9 & 11 & 12 & 4 & 47 \\
\hline Myotis mystacinus & & 2 & & - & 1 & 4 & 2 & 9 \\
\hline Myotis nattereri & 1 & 2 & 2 & 5 & 9 & 14 & 5 & 38 \\
\hline Barbastella barbastellus & - & 1 & 3 & 2 & 3 & 2 & - & 11 \\
\hline Plecotus auritus & 4 & 1 & 5 & 9 & 5 & 25 & 4 & 53 \\
\hline Total: & 1709 & 2437 & 5762 & 2698 & 15106 & 8478 & 4706 & 40896 \\
\hline
\end{tabular}

et al. 2019).

\section{Acknowledgements}

We thank late Dr. Jānis Baumanis (1940 - 2006) for being the soul and leader of the Pape station for 40 years (1966 - 2006). The trap construction in 2014 was financed by the Leibniz Institute for Zoo and Wildlife Research (Leibniz-Instituts für Zoo- und Wildtierforschung, Berlin, Germany), principal investigator Dr. Christian C. Voigt, and implemented by us - Institute of Biology, University of Latvia. We thank all involved personal and numerous volunteers during all the years as well as our families for support during our fieldwork. We acknowledge Ivo Dinsbergs, Ivars Kalvāns and Reinis Priedols for the drawings (Figures 1 and 2) and Jasja Dekker for the aerial image of the trap.

\section{References}

Baumanis J. 1995. Monitoring of migratory land birds in Pape seashore. Report of the Institute of Biology of the Latvian Academy of Sciences to the Environmental Consultation and Monitoring Center of the Ministry of Environment and Regional Development of the Republic of Latvia. 24 p. /in Latvian/

Belopolskii L.O. 1961. Activity of Biological Station of the Institute of Zoology Acdemy of Sciences USSR 1956-1959. In: Ecology and Migration of Baltic Birds. Riga, pp. 47-51./in Russian/

Blūms P., Baumanis J., Baltvilks J. 1967. Catching of migratory birds with nets 1966 in autumn in Latvia. Zoologijas muzeja biļetens 1: 103-106. /in Latvian/

Celmiņš A., Baumanis J., Reinbergs A., Roze V. 1986. Intensive bat migration in Pape in the autumn of 1985. Retie augi un dzīvnieki 1986: 52-58. /in Latvian/

Gatke H. 1895. The Birds of Heligoland. Edinburgh, Scotland.

Lindecke O., Elksne A., Holland R.A., Pētersons G., Voigt C.C. 2019. Orientation and flight behaviour identify the Soprano pipistrelle as a migratory bat species at the Baltic Sea coast. J. Zool. 308: 56-65.

Mihelsons H., Kasparsons G̦. Lejiņš G., Vīksne J., Šmits V., Lipsbergs J., Stolbovs I. 1960. Bird migrations in the Latvian SSR in the autumn of 1958. Latvijas Putnu dzìve-Ornitologiskie pètījumi 2. Latvijas PSR Zinātṇu akadēmijas Biologijas institūta raksti XIV: 139-192. /in Latvian/

Payevsky V.A. 2000. Rybachy-type trap. In: Busse P. (ed.) Bird Station Manual. Gdańsk University Press, Gdańsk, pp. 20-24.

Pētersons G. 2004. Seasonal migrations of North-Eastern populations of Nathusius bat Pipistrellus nathusii (Chiroptera). Myotis 41-42: 29-56.

Pētersons G., Celmiņš A. 1989. The greater mouse-eared bat Myotis myotis Borkhausen - a new species in the Latvian fauna. Retie augi un dzìvnieki 1989: 24-27. /in Latvian/

Tuttle M.D. 1974. An improved trap for bats. J. Mammal. 55: 475477.

Weigold H. 1922. Die wissenschaftliche Vogelfangstation zu Helgoland. Naturwissenschaften 44: 960-964.

Weigold H. 1924. VII. Bericht der Vogelwarte der Staatl. Biologischen Anstalt auf Helgoland. J. Ornithol. 72: 17-68.

Weigold H. 1956. How we began ringing on Heligoland. The Ring 8: $159-162$.

Woodford J., Hussel D.J.T. 1961. Construction and use of Heligoland traps. J. Field Ornithol. 32: 125-141. 